\title{
The Place of Africa in Global Economy: Nigeria in Perspective
}

\author{
Kolawole Ogunboyede \\ Department of Political Science and Public Administration, Adekunle Ajasin, University, Akungba-Akoko \\ kolawoleogunboyede@yahoo.com
}

\section{Doi:10.5901/mjss.2015.v6n2s1p213}

\begin{abstract}
The dominant feature of global economic trends in contemporary world system is globalization, which is being driven particularly by a new wave of information technology that is unparalleled in the history of human kind. Nation-State has consistently intensified efforts towards engaging in business across national borders and constructing production and distribution networks on a global scale. Global economy may be judged by many criteria, but the most important one is undoubtedly development in all its forms. Literature reviews indicate that many developing countries, Nigeria included are 'weeping baby' of globalization because they are at the receiving end. Nigeria is a cripple giant in the globalization wave because the economy in order to situate her more appropriately in the global trend and to understand the dynamic consequences of the process of global economy in Nigeria, the position of Nigeria and the role it plays in the international capitalist system. In order to illuminate the factors accountable for the skeweness towards the countries of the north, the paper adopts both descriptive and analytical methods. It also makes use of scientific analysis by employing dependency theory to explain the dynamics of the existing relationship between the Advanced Economies and the Third World Economies, the impact of such relationship skewed. The paper concludes and puts forth necessary recommendations to correct the global economic imbalance that will make Africa, and in particular to take her rightful place in the global economic system.
\end{abstract}

\section{Introduction}

Africa as a continent has always been in Dilemma of confronting the conflict of relevance in a world in which the developed nations dictate to the developing ones. A new pattern of international politics is emerging. The world is ceasing to be arena in which relatively self sustained "Sovereign" and homogeneous nations interact, collaborate, clash or make wars. It is known by many as the new "Global Village" given the unpredicted level of interconnectedness of political , economic, social and technological forces that permeate contemporary international system. Nation states have consistently intensified efforts towards engaging in business across national boarders and constructing production and distribution networks on a global scale.

Nigeria is being part of the global system has been battling with the problem of underdevelopment and how to reposition herself in order to be relevant in this dispensation. Many people especially the critical mind have been making a rethink on the issue of Nigeria development in this era of globalization. Olorede (2006) observed that "The exercise of rethink the world has become imperative because of the spread of development and the Plethora of development paradigms in the world today and the variegated consequence political formations that have developed from the forces in the world in the recent past"

Globalization has blown a serious wind in this new world system. Development of nations of the world is able to join the band wagon of globalization. The implication of this is that any Nation that does not have what it takes to join the globalization train is regarded as backward. The term "globalization" has been used by Scientist to connote or depicts the process of integration of the World social, economic, political and cultural values. Oddish (2000:159) argues that "The concept of globalization has been in vogue for about a decade now and it is expected that the new millennium will mark a strident and spirited pursuance of this global goal. The truth remains that in any human socio-economic interaction, the elements of profit and loss are never neglected. Thus, in most human organization, this trend indicates a skewed relationship between the units, while some gain, other lose. The global system has been classified into the North and the South, the rich and underdeveloped, industrialized and non-industrialized nations".

Based on the Modernization, dependency and under-development theories, there is belief that the relationship between the North and South is unequal, and the North has always lived off the economic endowment of the southern hemisphere, thereby making it poorer and underdeveloped. The disparity between the North and the South is visible in the areas of technological and economic endowment of the two. This sharp difference has made the North to be seen as 
underdeveloped and the south as developed.

The study recognizes the existence of a global environment that is deeply embedded in interdependency and the necessity for Nigeria to minimize the adverse effects of globalization while harnessing its benefits for national development. Globalization is the latest technological effort in reducing the physical distance among nations and societies of the world through information transfer at a speed that is hitherto unknown in information technology. The emergence of a unipolar world as a result of the disintegration of the former USSR, which effectively put an end to the cold war, has provided no feasible alternative to the western capitalist system along with its strong emphasis on market-driven and competitive economy. Hence, globalization has come to impose on every country the demand that her economy be competitive, market - driven, liberalized and with sufficient institutional framework to support it. The forces of globalization are so overwhelming that they leave no room for any country to stand alone. And because the new economic order is technology- driven, it is impersonal and has a virtual automatic response to changing situations. Having effectively replaced import substitution with foreign direct investment. Globalization has demonstrated its ability to build or ruin any economy at every short notice. In addition, globalization as idealized by experts is capable of socio-political and economic integration of countries in terms of free trade agreements, international financial market and transnational corporations, with the attendant positive effect on economic development.

It is obvious that Nigeria, though a politically independent sovereign state, cannot exist in isolation. Her present effort at privatization of some key government concerns, development of information, trade liberation and political democratization are necessary steps towards globalization as the world is moving in this twenty-first century.

This work will be looking at such relevant issues as

- The process of path to globalization in Nigeria.

- Advantage derivable from globalization (especially by a developing economy like Nigeria)

- Examination of possible alternatives to globalization (if there are any at all); and

- The roles of the public and private sectors of the Nigerian economy in our quest for globalization.

\section{Conceptualizing 'Globalization'}

The concept 'globalization' contains the hypothesis that there has occurred an increase in the density of contacts between locations worldwide, (Gidden, 1990:56), that occur life is now structured in such a way that social interactions are embedded in global networks and that local happenings are shaped by events occurring many miles away and vice versa (IBID). Globalization could be viewed as a liberal concept for exploitation, domination, imperialism, and the overall reproduction of injustice, inequalities and poverty that characterized the relations among nations. Also, it could be projected as the long awaited magic wand required to solve global, economic, security, environmental and political difficulties.

Globalization is an integral part of human history. In its most generic and broadest sense, it is part of the movement of history. All through the history of man, we have noticed forces which seem to push for greater integration of human activities. In this context, is a process of increased integration of national economies with the rest of the world to create a more coherent global economy. It is a process of integrating economic decision making such as the consumption, investment, and saving process all across the world. It is a process of creating a global market place in which free markets, investment flows, trade and information are integrated. It is a process of heightening the level of interconnections between nation - states. Globalization can also be defined as the process of shifting autonomous economies into the global market- the systematic integration of autonomous economies into a global system of production and distribution. It implies a world in which development in one region can come to shape the life chances of communities in distance parts of the globe. Its embrace and impact is uneven. It divides and it also integrates. It brings fortune as well as misfortune depending on the readiness to embrace it and commitment to issue of governance in a particular nation or region.

For the IMF, "globalization means more closely integrated goods, services. And capital markets......." (IMF survey , 1997 : 275) for Thomas L. Friedman (1999 : 1), globalization is " the integration of markets, finance and technologies in a way that is shrinkling the world from a size small and enabling each of us to reach around the world farther, faster and cheaper than ever before. Like all previous international systems,. It is directly or indirectly shaping the domestic politics, economic policies and foreign relations of virtually every country". What is important to recognise is that within globalization, new economic, environmental, social, cultural and technological relations are emerging.

The world is currently being, and will in the forseeable future, be driven by the following three main forces of globalization: 
a. Technology - especially the stupendous growth in telecommunications and information technology.

b. Economic liberation - as shown by the wide acceptance of the open market, competitive system and macroeconomic producense and

c. Democracy - and its associated concepts of human rights, transparency. Etc

In this paper, the third force of globalization which is democracy will be the major concern to determine the extent at which the democratic structure in Nigeria is positioned to maximized the benefit of globalization in this $21^{\text {st }}$ century.

The general acceptance of democratic systems of governance and their associated concepts and institutions - like separation of powers, strong policing and judicial systems, a free press, transparency, accountability, responsibility, patriotism, etc. Democracy, even though varied in form, has become widely accepted globally as the form of governance through which the wishes and aspirations of the majority of the populace are best realized.

\section{Theoretical Framework}

In this research work, political economy as an approach would be employed as the theoretical framework.

The millennium programme represented a cycle of ideas and a dictate of political and economic interest of the development nations to strangle the economies of poor countries.

Africa's history of unequal relations with the developed world in the last three centuries is such that it has largely become a non-autonomous actor without the capacity to decide its own fate and future, NEPAD by being a historical does not constitute an adequate response to the continent's underdevelopment.

Political economy as an approach or tool of analysis is, in the main, not an offspring of the Marxian historical and dialectical materialism.

As an approach, political economy probes into the depth of issues, the interconnection of phenomena, polities etc, with a view to knowing their class origin, character and composition and the logic of their existence and future. It does not therefore examine issues superficially.

In this sense, political economy is not and cannot be reduced to the study of capitalism.

The political economy approach has been used by scholars with Marxian persuasion to undertake various studies ranging from the process of colonization and decolonization, underdevelopment and dependency, political instability, the activities of MNCs, the world Bank and the IMF, the "dept trap" of TWCS, etc.

It should emphasized that the essence of political economy is to penetrate deep into processes and policies lay bare their essence and then explain concrete forms of their manifestation in everyday life. The believe that the rich are rich because they are rich and the poor are poor because they are poor is a tautological claim which Marxian political economy approach disapproved as unscientific, a historical and politically faulty.

The theory of political economy itself deals with the basis of social development in any society. The production of material wealth the mode of production.

According to V.I Lenin, political economy is not all concerned with production but with the social relations between people in social production, the social system of production.

Thus, political economy is a science of the study of society and it reveals the basis for change and development in the society. The world economic system that is essentially capitalist promotes an international division of labour in which manufacturing technology and finance capital are the prerogative of the industrialized capitalist countries (10cs) of the west, while the third world countries were forcefully made to specialize in the production and supply of primary products, whose price are determined by the 10cs. This unjust and unbalanced international division of labour was achieved through the process and logic of colonialism driven by imperialism. The world economic system has strategically put the poor countries of the south perpetually at a disadvantaged position, through the political legislation of the Bretton woods system that hegemonized the Euro-dollar as an international currency of convertibility and a gold reserve.

In order to sustain the world economic system, there was the need to establish an international capitalist financial system. It is worth noting that at the meeting where the two major multi-lateral institutions World Bank and International Monetary Fund (IMF) were established, non of the third world countries was present.

Thus, little wonder that those institutions were controlled by western financial interest. The recent World Bank presidential election which involved a Nigerian (Dr. Mrs. Okonjo Iweala) supported this position.

However, the orientation and policy objectives of both world bank and the IMF have changed with time. As argued by Onimode, "Since 1979 IMF has been offering more assistance to third world countries under its stand-by arguments of extended fund facility, though with harsh conditions. These include trade liberalization; monetary anti-inflationary measures; fiscal anti-inflationary programmes; anti - inflationary control of wage increase; open door policy on foreign investment and multinational corporations; reduction of spending on social services, privatization of public enterprises etc. 
A critical look at the foregoing conditions will reveal their pernicious effect on the third world countries who are caught in a "debt trap" and who are to take these bitter pills. The adoption of these policy measures and initiatives couched in economic liberalism has further pauperized Third world countries and made their crises assume a tragic proportion, especially under the renewed globalization policy which has made them to be more dependent and subservient to the west.

\section{Globalization and the Politics of Global Economic Relation: Nigeria Experience}

As part of the conditionality's given by the International Monetary Fund (IMF) is that nation- state must democratized. Political globalization examines the nexus of globalization and state power, globalization and democratization. While growing transnational economic and culture relations may have reduced the redistributive capacities and legitimacy of the state, the state still play three key roles, as regulator thus providing legitimacy for international economic regulations and stability to financial markets, as mechanism of social cohesion and economic cooperation between the major or social groups at the nation state level, and as guarantor of the rule of law. The state is an insulator against external shocks, and alleviates market distortions. Globalization also depicts the growing power of capital over the social classes thus narrowing the democratic space. Further, the public policy process is less amiable to the influence of the mass of people as a result of globalization; still the global space lacks democratic structures that are rooted in the global citizens. Capitalist globalization neither fosters nor forecloses prospects for democratic struggles at local, national and global levels. Thus, the struggles against authorization structures and regimes especially in nation- states undergoing orthodox adjustment co- exist with the growth of local resistance groups identify politics, and the struggle by the powerless, disenfranchised, dislocated and immoderate working people against the impacts of globalization.

It is a known fact that politicians cannot be ignore because they determine the state of our political, economic and socio- economic system within which will try to manage our economy. That of course situates Nigeria' development arrest within the matrix of our persisting leadership question that national economic cannot be jumpstarted or turned around in the absence of clear- headed, imaginative and focused leaders who can walk the talk about reforms.

Failure to imbibe the tenets of democracy will make African states and Nigeria in particular not to maximize the benefits of globalization.

Politics largely determines the framework of economic activities and channel it in the direction intended to serve the interest of dominant groups; the exercise of power in all its is a major determinant of the nature of economic system. On the other hand, the economic process itself tends to redistributes power and wealth. The last year election into the headship of World Bank is another way of exhibiting domineering attitude of the west over the third world countries. Dr. Ngozi Okonjo-Iweala, a Nigerian and minister of finance who has worked with World Bank for almost three decades with an impressive academic training. Her candidacy stirred enthusiasm of support even from abroad compared to Dr. Jim Yong Kim a Korean American which many people raised doubt over his experience and qualification.

However, the Bank is accused of many things that demand attention; among them are lack of transparency and accountability in its governance. But what has eroded the institutions' moral foundation and put into question its legitimacy as a global development agency is the systemic institution bigotry against people of third world countries. It is obvious and pragmatically clear that power structure in the World Bank is heavily based on individual subscription. It is unfortunate that, the two financial institutions

World Bank and IMF that are canvassing that all members state must be democratized equally exhibited the undemocratic attitude by not based the election of the two institutions on one man one vote but vote is based on financial strength and commitment of member states. The United State alone has more than a quarter of the votes and with U.K, France, Canada and Australia. The United States controls over 50\% of the total vote cast, it is obvious who controls the bank. Equally important is the fact the upper echelon of the bank is dominated by American, British, German and French citizens. The president who is the chief executive, has always been an American and again, always a male. Also, the leadership of IMF is in tandem with the World Bank. 
Table 1: World Bank Presidents Since Its Inception

\begin{tabular}{|c|l|l|l|}
\hline & Name & Country & Period \\
\hline 1 & Eugene Meyer & Los Angeles, USA & June 1946-Dec 1946 \\
\hline 2 & John Jay Mccloy & Philadelphia, USA & March 1947-June 1949 \\
\hline 3 & Eugene Robert Black & Atlanta, Georgia, USA & July 1949-Dec 1962 \\
\hline 4 & George David woods & Boston, USA & January 1963-march 1968 \\
\hline 5 & Robert strange Mcnamara & Oakland, Califonia, USA & April 1968-June 1981 \\
\hline 6 & Alden Winship Clausen & Hamilton, Illinois, USA & July 1981-June 1986 \\
\hline 7 & Barber Conable & Warsaw, New York, USA & July 1986-August 1991 \\
\hline 8 & Lewis.T. Preston & New York, USA & Sept 1991-May 1995 \\
\hline 9 & James D. Wolfensohn & Sydney, Australia & June 1995-May 2005 \\
\hline 10 & Paul Wolfowitz & New York, USA & June 2005 - June 2007 \\
\hline 11 & Robert B. Zoellick & Naperville, Illinois, USA & July 2007-June 2012. \\
\hline 12 & Dr. Jim Yong Kim & USA & July 2012 - till date \\
\hline
\end{tabular}

Source: World Bank Archive

Table 2: International Monetary Fund ( Imf) Managing Directors Since Its Inception

\begin{tabular}{|c|l|c|l|}
\hline & Names & Country & Period \\
\hline 1 & Camille Gutt & Belgium & May 61946-May 51951 \\
\hline 2 & Ivar Rooth & Sweden & August 1951-Oct 1956 \\
\hline 3 & Per Jacobsson & Sweden & Nov 1956-May 1963 \\
\hline 4 & Pierre-Paul Schweitzer & France & Sept 1963-Aug 1973 \\
\hline 5 & H. Johannes Witteveen & Motherlands & Sept1973-June 1978 \\
\hline 6 & Jacques de Larosiere & France & June 1978-Jan 1987 \\
\hline 7 & Michel Camdessus & France & Jan 1987-Feb 2000 \\
\hline 8 & Mr Horst Kohler & Germany & May 2000-March 2004 \\
\hline 9 & Mr. Rodrigo de Rato & Spain & June 2004-Oct 2007 \\
\hline 10 & Mr Dominique Stravess-kahn & France & Nov 2007-May 2011 \\
\hline 11 & Madame Christine Lagarde & France & July 5-till now \\
\hline
\end{tabular}

Source: Imf Archive

Table 1 and 2 showed the economic subservient and master- servant relationship which is the global manifestation of the skewed system thriving in the international economic and political system. There is a hidden agenda behind globalization and this is to further weaken the structure of the third world economic and make them more successtible to penetration by foreign capital with a view to consolidating the hegemony of the western industrial economics, "the owners" of globalization, over the entire global economic system, and to weaken internal social cohesion in the third world nations thus making the task of nation building and the promotion of egalitarianism more complex than it ordinarily should be. The above analysis equals the nature of the challenges faced by the long disadvantage in a global system that is fundamentally skewed against them. Most of the riches of the north are generated at the expense of the south is undoubtedly the structure of the international economic system.

Mimiko (1997) argued that it is the imperialist nature of the system much more than third world domestic policies, important as they are, that constitutes the "causative factor" of the south's underdevelopment.

Regrettably, as Ake argued,

We have pursued development with a confusion of purposes and interests and with policies full of ambiguities and contradictions. The problem lies with the major agents of developments: our governments, the multinationals, IMF, The World Bank, and. Imperial powers. Each of them propagates an idea of development corresponding to its interests and images of the world

Recently, a senior resident representation mission chief of IMF in the country, Mr. Williams Rogers, urged the Nigerian government to remove subsidy on fuel completely to ensure fiscal adjustment and plan for savings in recurrent spending. IMF advised Nigeria not to build refineries when it knew that the country needed it to generate huge revenue 
from the sale of petrol refined locally. Last year the IMF and its local lackeys claimed that the economy would collapse if petrol was not sold at N141 per litre. But with massive strike and protests, the price was reduced to N 97 and the economy has not collapsed now. It is pertinent to ask the IMF/World Bank to name one developing country they have advised out of underdevelopment and poverty. The records one sees are record of failure because the developing countries are still running to IMF/World Bank for financial bailout. However, this is not in any way to suggest that the internal economic policies of the south do not have a role to play in the crises that have come to define the reign. The primary culprit in African's and Nigeria in particular continuing underdevelopment is the ruling elite, the failure of leadership or failure of government.

African states and Nigeria in particular will find it difficult to harness the forces of globalization to advance development because of leadership failures. Hardly one will find a country in Africa that is crises free. African states are states of turmoil e.g. ethnic crises, religions crises, political crises, seperationism, border dispute, terrorism etc.

Since Nigeria returned to democracy in 1999, political regime has inundated the citizens with its political and economic agenda. As the largest and most populous black country in Africa, Nigeria is blessed with large arable land and all sorts of mineral resources. The failure of democracy to engender development is therefore inextricably tied up to the nature of the Nigeria state whose origin and initial goal was not to pay any serious attention to the problem of the subjects but to exploit the people and their resources to serve the goal of metropolis. Right into the twenty first century, Nigeria cannot feed her citizens, just as it is economically and technologically backward. The country's level of poverty has reached such alarming state that it has become one of the poorest countries in the world. Obnoxious leader of the country has made democratic system a stagnant one. Dysfunctional political system, electoral fraud, money politics, injustice, corruption and mismanagement have also produced devastating effect on the democracy in Nigeria. Leadership has been generally ineffective both in terms of the degree of institutionalization of leadership and political power as well as in terms of the level of government output. There is the absence of a national political class with a national class project.

However, most of these democratic problems in Nigeria started from the electoral fraud through rigging and harassment. Once the election is not free and fair, it will produce a weak leader that lack the political will to initiate economic policies that will position the nation for economic development. The leadership is infested with corruption and lack of the culture of accountability. Currently, Nigeria government is paying lip service to reduce corruption among Nigerian leaders.

It is pathetic that there is the continued attachment of the Nigerian leaders to their colonial precursors. This has resulted in a dependent, non- autonomous leadership. The Nigerian situation presents a situation of an overhang of continues collaboration with metropolitan interests to despoil their own people. Essentially, Nigeria has been infested with corrupt leadership totally insensitive to the suffering of their subjects.

\section{Conclusion and Recommendations}

The nature of society inherited from the British imperialists made it so difficult, if not impossible, for anything to work in Nigeria. Colonialism altered, deterred and retarded, to some extent, the existing traditional society and their pace of development. A Nigeria that was bequeathed was one that lacked adequate capital, markets and the appropriate technology to industrialize and favourably compete in the international world capitalist market.

African states economies is euro -centrically tied to the world market, that is, their production strategy is influenced by the demand of the world market which is determined almost exclusively by the pattern of production and consumption within the capitalist and America. It is obvious that the historical context of the Nigeria state and its development paradigm as well as its leadership have all conspired to create at empirical level of a pseudo -development for the country.

Globalization presents both risk and opportunities for African countries. The risks spring from the fact that the benefits of their integration into global economy will be lopsided except the state realize the potential benefits and harness such.

Granted the complex challenges facing African states and Nigeria in particular in the global economic relations, it becomes appropriate to put forth the following measures to address and arrest this ugly trend

- African has to look inwards for a homegrown development strategy that is compatible with globalization.

- Fight institutionalized corruption: African countries and Nigeria in particular has become a dwelling place for corruption, where the government of the day practices kleptocracy. There is need to strengthen anti-corruption crusade and reformation of values and behavior patterns, establishing a culture compatible with developing a modern, free market democracy. 
Nigeria is advised to take seriously the issue of security especially to tackle decisively, the issue of Boko Haram and Niger- Delta militancy. Nigeria should also try as much as possible to nip in the bud the ubiquitous electoral shenanigans it has been globally identified with.

Similarly, if the third world countries must be the Bride of many nations, it must have a sense of indigenous economic development, that is, the third world countries must opt-out from the world market economic corruption as Albania and North Korea did and started producing to develop it internal technological base and transforming the economy from its colonial externally responsive structure to one which is internally responsive.

More so, the third world countries must endeavor to liberate their economic out of the web of the western dominated through effective utilization of it domestic resources generated within the domestic economy.

The third world countries must have a sense of internal direction which will usher in the development of material and technological base of internal cohesion. Despite the fact the third world countries economies is externally responsive, that is, producing to feed the world market, yet the third world countries need to evolve home grown economy which is capable of fostering the development of its internal technological base and material where withal.

\section{References}

Orimode. B. (1995): "African Alternative to Structural Adjustment Programme." Economic Research Center ERC Working Paper. No. $03 / 09$.

Ajayi I.B, (2004): Issues of Globalization in Africa: The Opportunities and the Challenges. Ibadan Journal of the Social Sciences Vol. 2. No. 1.1-21.

Lenin V.I., (1975): Imperialism, The Highest Stage of Capitalisation, Peking: Foreign Languade Press.

Onimode B., (1988): A Political Economy of the Africa Crisis, London: Zed Booksa Ltd.

Onimode B., (2000): African in the World of the 21st Century, Ibadan: Ibadan University press.

Giddens A., (1990): A New World Order, London: Printers Publishing \& Co.

Mimiko N.O., (1997): The Global Village: Selected Topic in International Economic Relations. Akure. Nigeria: ABN Research and Service.

Ake C., (1996): Democracy and Development in Africa, Washington D.C: African Books Collective Publishers.

Ake C., (2000): "The State in Contemporary Africa" in Nnoli, O. (eds): Government and Politics In Africa. Harare: AAPS Book Publishers. Friedman T.L., (1999): "Duelling Globalisations" in Foreign Policy Fall. Website Version

Arowolo D., (2008): Contemporary Issues in International Relations. Lagos: Prince way-Gbade Publications. Pg. 137-142.

Shamsuddeen U., (1999): Implications of Globalisation for the Nigerian Economy. A paper Delivered at the Conference Organised by the Nigerian Economic Society, Lagos. February.

Olorode O., (2006): The World in Perspective. Ile-lfe. LST Publisher.

Oddish O., (2000): Globalization and Nigeria's Foreign Policy in the New Millennium. Enugu. John Jacob's Classical Publication. 